\title{
Scale Construction for Measuring the Attitude of Sericulture Beneficiary Farmers towards the Activities of Technical Service Centres (TSCs)
}

\author{
N. Harisha ${ }^{1}$, B. Mukunda Rao ${ }^{2}$, T. Gopi Krishna ${ }^{3}$, M. Uma Devy ${ }^{2}$ \\ and S. K. Nafeez Umar ${ }^{4}$ \\ ${ }^{1}$ Department of Agricultural Extension, Agricultural College, Bapatla, ANGRAU, A.P, India \\ ${ }^{2} \mathrm{O} / \mathrm{o}$ Dean of Agriculture, ${ }^{3} \mathrm{O} / \mathrm{o}$ Director of Extension, ANGRAU, Lam, Guntur, India \\ ${ }^{4}$ Department of statistics and Computer Applications, AG College, Tirupati, India \\ *Corresponding author
}

\section{A B S T R A C T}

\begin{abstract}
Sericulture is an agro-based, labour intensive, export oriented commercial activity. Sericulture which was considered as a subsidiary occupation in the past is now being considered as major activity and farmers are willing to take-up large-scale sericulture. To, improve mulberry area and cocoon production, The Government of Karnataka and department of sericulture started a new demand driven extension approach called Technical Service Centres (TSCs) at the grass-root level (Hobli and Taluka level). The main function of TSCs is to transfer of sericulture technologies through extension activities and distributing extension services among sericulture farmers. It is necessary to Scale Construction for Measuring the Attitude of Sericulture Beneficiary Farmers towards the Activities of Technical Service Centres (TSCs). The Likert attitude scale was prepared for the study. Total of 60 statements were prepared, which represent attitude of sericulture beneficiary farmers towards activities of TSCs. Finally 54 statements were selected after editing. The relevancy test done by 52 judges out of 105 judges including Professors, KVK SMS, Ph. D Scholars. Accordingly, statements having relevancy percentage $>75$, relevancy weightage $>0.70$ and mean relevancy score $>2.5$ were considered for final selection of statements. Hence, 40 statements were selected after scrutiny. The 40 statements representing the attitude towards functioning of TSCs were administered to 100 sericulture farmers in non-sample area with five continuum containing Strongly agree, Agree, Undecided, Disagree and Strongly disagree with the scoring pattern 5, 4, 3, 2 and 1 respectively for positive statements and reverse for negative statements. After computing the $\mathrm{t}$-value for the statements, the thumb rule of rejecting items with ' $t$ ' value less than 1.75 was followed. Thus, the statements having the highest $\mathrm{t}$-values were selected. Thus, a total of 21 statements were selected. The Rulons reliability coefficient $\left(r_{t t}\right)$ value is 0.86 , which explains about 86.00 per cent of scale accuracy.
\end{abstract}

\section{Keywords}

Attitude, Scale,

Relevancy,

Reliability

Article Info

Accepted:

22 July 2020

Available Online:

10 August 2020

\section{Introduction}

Sericulture is an agro-based, labour intensive, export oriented commercial activity.
Sericulture which was considered as a subsidiary occupation in the past is now being considered as major activity and farmers are willing to take-up large-scale sericulture. It 
provides an ideal livelihood opportunity for millions of women without disturbing their household work. Silkworm rearing can generate regular employment for 12-13 persons per ha with low investment and a short gestation period of six months.

The sericulture has a unique extension system as like agriculture. The research-extensionfarmer linkage plays a vital role for sustainable development of sericulture. The aim of agricultural extension is to improve the standard of living of farmers, not the farm and the purpose is to enhance learning. Through the ages, learning has been as vital as other functions like production, marketing of occupations and supply of inputs. Further, agricultural extension explores the functions like communicating sericulture research findings and recommendations to farm people and bringing farm people into contact with sources of practical and useful information through organized group action. Agricultural extension is commonly identified with activity whereby sericulture extension workers interact with and teach the farmers about improved farming practices. Agricultural extension organization provides them with a constant supply of useful extension messages, technical and administrative supervision.

In view of the aforementioned gaps, the Government of Karnataka and department of sericulture started a new demand driven extension approach called Technical Service Centres (TSCs) in the year 2005-06 at the grass-root level (Hobli and Taluka level). There are 246 Technical Service Centres established in the state to perform the extension task. Each TSC is headed by one Sericulture Extension Officer and having two sericulture demonstrators for execution of extension activities at grass root level. These centres mainly involved in the dissemination of the technologies developed by the Research Institutes and also in supply of mulberry cuttings/saplings, monitoring mulberry cultivation, silkworm rearing and providing information about loan facilities and subsidy schemes. They are also involved in distribution of extension services among sericulture farmers under Karnataka Sericulture Project, RKVY and PM Kisan Sinchayi Yojana. In addition to this, Technical Service Centres are also involved in crop- inspection, disinfection of rearing houses to control the silkworm diseases, conducting group discussions, field days, workshops, study tours, state level seminars, conducting training camps to men and women sericulture farmers. The extension officers and staff working in seed areas have the responsibility of inspecting the seed crops thoroughly and certifying the disease freeness of the crops in the field.

The TSC is the distinctive extension system established at grass root level, which are easy accessible to farmers and helps to disseminate knowledge and make for them adopt the scientific technologies of mulberry cultivation and silkworm rearing. The extension efforts of TSCs are evident for increase production, productivity and quality of mulberry and cocoons. In this context, it is necessary to study the impact of TSCs in terms of direct and indirect changes as perceived by sericulture farmers, and attitude of sericulture beneficiary farmers towards the activities of TSCs. All the findings of the study help to refinement and reformation of extension methodologies of TSCs. It also helps to know the efficacy of TSC extension personnel by measuring knowledge and adoption of recommended technologies of mulberry and silkworm rearing among sericulture beneficiary farmers.

\section{Materials and Methods}

Attitude is operationally defined as positive or negative responses about working of TSCs by the sericulture beneficiaries (Table 1-3). 
The attitude of the sericulture farmer towards functioning of TSCs was measured by the attitude scale especially constructed to meet the objectives. Attitude in the present study as defined by Likert (1932) is "the best technique available for investigating the attitude of the individual about some psychological object on the psychological continuum."

Likerts summated rating technique was used to construct the attitude scale because the technique has high reliability co-efficient and it gets a 4 or 5 point judgment on each item rather than mere acceptance or rejection.

\section{The steps used in construction of attitude scale are as follows}

\section{Collection and editing of items}

The summated rating scaling techniques was used for measuring the attitude of TSCs beneficiaries.

The total of 60 statements were prepared which represents the attitude of sericulture farmers towards functioning of TSCs, which were compiled from diversified sources viz., literature and interaction with the experts and then editing on the basis of criteria suggested by Edward. Finally 54 statements were selected after editing.

\section{Relevancy test}

The statements representing the attitude of sericulture farmers towards functioning of TSCs were sent to 105 judges, out of that to 52 judges were administered including professors, KVKs Subject Matter Specialist, $\mathrm{Ph}$. D scholars. The judges were asked to indicate their relevancy with each statement on four point continuums ranging from "More Relevant" to "Not Relevant". The scoring pattern adopted was 'More Relevant' (4) response, 'Relevant (3) response', 'Least
Relevant (2) and 'Not Relevant' (1) response. After the collection of the judgments, the responses were subjected to analysis and Relevancy Percentage, Relevancy Weightage and Mean relevancy Score were calculated which are defined as follows:

\section{Relevancy Weightage (RW)}

It is the ratio of actual score obtained to the maximum possible scores obtainable for each statement.

Relevancy Weightage $=$

Actual Score obtained per each item

Maximum possible score per each item

\section{Relevancy percentage (RP)}

It is the number of respondents who rated the statements as 'most relevant' and 'relevant', which is converted into percentage.

Relevancy Percentage $=$

Frequency Score

Number of Respondents

\section{Mean Relevance Score}

It is the ratio of actual score obtained by each respondent to the number of judges responded for the variable.

Mean Relevancy Score $=$

Actual Score obtained per each item

Number of judges responded

Accordingly, statements having relevancy percentage $>75$, relevancy weightage $>0.70$ and mean relevancy score $>2.5$ were considered for final selection of statements. Hence, 40 statements were selected after scrutiny. 


\section{Item analysis}

The statements representing the attitude towards functioning of TSCs were administered to 100 sericulture farmers in non-sample area. The sericulture farmers were asked to indicate their degree of agreement or disagreement with each statement on five-point continuum containing Strongly agree, Agree, Undecided, Disagree and Strongly disagree with the scoring pattern $5,4,3,2$ and 1 respectively for positive statements, if it was a negative attitude statement the scoring pattern was reversed viz. Strongly agree (1), Agree (2), Undecided (3), Disagree (4) and Strongly disagree (5) in that order. Their response was recorded and the summated score for all the statements was obtained. For each individual the maximum possible score on 40 statements is 200 and the minimum possible score is 40 . The scores of the sericulture farmers were arranged in descending order. Twenty five per cent of the highest and 25.00 per cent of the lowest scores were taken for the item analysis. These responses were subjected to item analysis for selection of the items that constitute the final attitude scale.

$\mathrm{t}=\frac{\overline{\mathrm{x}}_{\mathrm{H}}-\overline{\mathrm{x}}_{\mathrm{L}}}{\sqrt{\frac{\mathrm{s}_{\mathrm{H}}^{2}}{\mathrm{n}_{\mathrm{H}}}+\frac{\mathrm{s}_{\mathrm{L}}^{2}}{\mathrm{n}_{\mathrm{L}}}}}$

Where,

$\overline{\mathrm{x}}_{\mathrm{H}}=$ The mean score on a given statement for the high group

$\overline{\mathrm{x}}_{\mathrm{L}}=$ The mean score on a given statement for the low group
$\mathrm{S}_{\mathrm{H}}^{2}=$ Variance of the distribution of the responses of the high group to the statement $\mathrm{S}_{\mathrm{L}}{ }^{2}=$ Variance of the distribution of the responses of the low group to the statement

$\mathrm{n}_{\mathrm{H}}=$ Number of sericulture farmers of high group

$\mathrm{n}_{\mathrm{L}}=$ Number of sericulture farmers of low group

High group $\left({ }^{n_{H}}\right)$ was equal to low group $\mathrm{n}_{\mathrm{L}}$ (25 per each group) statements, $t$ - values was calculated by using modified formula. The formula was:

$$
\mathrm{t}=\frac{\overline{\mathrm{x}}_{\mathrm{H}}-\overline{\mathrm{x}}_{\mathrm{L}}}{\sqrt{\frac{\left(\mathrm{x}_{\mathrm{H}}-\overline{\mathrm{x}}_{\mathrm{H}}\right)^{2} \pm\left(\mathrm{x}_{\mathrm{L}}-\overline{\mathrm{x}}_{\mathrm{L}}\right)^{2}}{\mathrm{n}(\mathrm{n}-1)}}}
$$

After computing the t-value for the statements, the thumb rule of rejecting items with ' $t$ ' value less than 1.75 was followed (Edwards, 1957). Thus, the statements having the highest $\mathrm{t}$-values were selected. Thus, a total of 21 statements were selected. The tvalues of selected statement for attitude scale as given below.

\section{Standardisation of the scale}

The scale developed was further standardized by establishing its reliability and validity.

\section{Reliability}

According to Kerlinger (1964) "Reliability is the accuracy or precision of measuring instrument". The Rulens formula was used to find reliability of scale. 
Table.1 Relevancy weightage Mean relevancy score, and relevancy percentage of the statements based on the responses given by judges

\begin{tabular}{|c|c|c|c|c|}
\hline \multirow[t]{2}{*}{ S. No } & \multirow[t]{2}{*}{ Statements } & \multicolumn{3}{|c|}{ Relevancy } \\
\hline & & $\begin{array}{l}\text { Relevancy } \\
\text { Weightage }\end{array}$ & $\begin{array}{l}\text { Relevancy } \\
\text { Percentage }\end{array}$ & $\begin{array}{l}\text { Relevancy } \\
\text { Score }\end{array}$ \\
\hline $\mathbf{1}$ & $\begin{array}{l}\text { Trench method of mulberry planting } \\
\text { supported by TSC's improves water } \\
\text { use efficiency. }\end{array}$ & 0.82 & 82.5 & 3.3 \\
\hline 2 & $\begin{array}{l}\text { In my view trainings of TSC's are } \\
\text { helpful for knowledge and skill up } \\
\text { gradation of sericulture farmers. }\end{array}$ & 0.85 & 85.83 & 3.4 \\
\hline 3 & $\begin{array}{l}\text { Work efficiency of staff of TSCs is } \\
\text { acceptable. }\end{array}$ & 0.76 & 76.66 & 3.06 \\
\hline 4 & $\begin{array}{l}\text { Sericulture insurance provided by } \\
\text { TSCs is essential against risk and } \\
\text { uncertainty. }\end{array}$ & 0.85 & 85.83 & 3.43 \\
\hline 5 & $\begin{array}{l}\text { TSC is a good initiative in motivating } \\
\text { the farmers to adopt innovative } \\
\text { technologies. }\end{array}$ & 0.85 & 85.83 & 3.43 \\
\hline 6 & $\begin{array}{l}\text { TSC established at hobli level is more } \\
\text { convenient for extension services to } \\
\text { the farmers. }\end{array}$ & 0.78 & 78.33 & 3.13 \\
\hline 7 & $\begin{array}{l}\text { I feel happy with frequent crop } \\
\text { inspection done by the officials of } \\
\text { TSCs. }\end{array}$ & 0.77 & 77.50 & 3.10 \\
\hline 8 & $\begin{array}{l}\text { As per my view Extension officials of } \\
\text { TSC's are technically sound for } \\
\text { smooth running of activities of TSC. }\end{array}$ & 0.81 & 81.66 & 3.26 \\
\hline 9 & $\begin{array}{l}\text { Market information disseminated by } \\
\text { the TSCs is highly useful for getting } \\
\text { remunerative prices for cocoons. }\end{array}$ & 0.82 & 82.50 & 3.30 \\
\hline 10 & $\begin{array}{l}\text { TSCs are farmers welfare oriented } \\
\text { extension reform. }\end{array}$ & 0.82 & 82.50 & 3.30 \\
\hline 11 & $\begin{array}{l}\text { Digital transfer of subsidy amount by } \\
\text { the TSC's to the farmers account is a } \\
\text { novel method to reduce the misuse of } \\
\text { funds. }\end{array}$ & 0.82 & 82.50 & 3.30 \\
\hline 12 & $\begin{array}{l}\text { I feel that TSC is play an incredible } \\
\text { role in encourage the farmers to take } \\
\text { up sericulture as a main occupation. }\end{array}$ & 0.80 & 80.33 & 3.23 \\
\hline 13 & $\begin{array}{l}\text { Agri entrepreneurship is possible } \\
\text { through TSCs for making agriculture } \\
\text { as an agri business. }\end{array}$ & 0.82 & 82.50 & 3.30 \\
\hline 14 & TSC's can empower women through & 0.81 & 81.66 & 3.26 \\
\hline
\end{tabular}




\begin{tabular}{|c|c|c|c|c|}
\hline & sericulture. & & & \\
\hline 15 & $\begin{array}{l}\text { I feel attraction of Youth towards } \\
\text { agriculture is possible through } \\
\text { extension activities of TSC. }\end{array}$ & 0.80 & 80.33 & 3.23 \\
\hline 16 & $\begin{array}{l}\text { TSCs are working towards improving } \\
\text { of farm income of sericulture. }\end{array}$ & 0.77 & 77.50 & 3.10 \\
\hline 17 & $\begin{array}{l}\text { Farmers- scientist- extension } \\
\text { approach is needed for development } \\
\text { of demand driven technologies. }\end{array}$ & 0.78 & 78.33 & 3.13 \\
\hline 18 & $\begin{array}{l}\text { TSCs are supplying high quality } \\
\text { disinfectants i.e., formaldehyde, } \\
\text { bleaching powder, sprayer etc, to the } \\
\text { beneficiaries. }\end{array}$ & 0.77 & 77.50 & 3.10 \\
\hline 19 & $\begin{array}{l}\text { Regular rapport with TSCs, which } \\
\text { facilitates for improvement of } \\
\text { leadership quality in society. }\end{array}$ & 0.81 & 81.66 & 3.26 \\
\hline 20 & $\begin{array}{l}\text { TSCs will create a positive impact on } \\
\text { sericulture development in Karnataka. }\end{array}$ & 0.90 & 90.00 & 3.60 \\
\hline 21 & $\begin{array}{l}\text { *TSCs is giving more importance to } \\
\text { large farmers than small holders }\end{array}$ & 0.85 & 85.00 & 3.40 \\
\hline 22 & $\begin{array}{l}\text { I satisfied with criteria for selecting } \\
\text { the farmers by TSC's to distribution } \\
\text { of subsidized inputs. }\end{array}$ & 0.81 & 81.66 & 3.26 \\
\hline 23 & $\begin{array}{l}\text { TSCs help to recognize the innovative } \\
\text { farmers for awards during Kisan } \\
\text { Melas. }\end{array}$ & 0.85 & 85.00 & 3.40 \\
\hline 24 & $\begin{array}{l}\text { Kisan Melas are organized by TSC's } \\
\text { at hobli level are useful to enrich the } \\
\text { knowledge on sericulture } \\
\text { technologies. }\end{array}$ & 0.83 & 83.33 & 3.33 \\
\hline 25 & $\begin{array}{l}\text { *TSCs should work more in } \\
\text { traditional area rather than non- } \\
\text { traditional sericulture area. }\end{array}$ & 0.80 & 80.00 & 3.20 \\
\hline 26 & $\begin{array}{l}\text { Mechanization in Sericulture } \\
\text { recommended by TSC's is need of } \\
\text { the hour for reducing the cost of } \\
\text { cultivation. }\end{array}$ & 0.83 & 83.33 & 3.33 \\
\hline 27 & $\begin{array}{l}\text { TSCs promoting Good Agricultural } \\
\text { Practices (GAP) practices in } \\
\text { sericulture. }\end{array}$ & 0.81 & 81.66 & 3.26 \\
\hline 28 & $\begin{array}{l}\text { The single window system adopted in } \\
\text { TSC's is able to solve the problems of } \\
\text { farming community. }\end{array}$ & 0.80 & 80.00 & 3.20 \\
\hline 29 & $\begin{array}{l}\text { I feel that information transmitted by } \\
\text { TSC's through mobile SMS services }\end{array}$ & 0.77 & 77.50 & 3.10 \\
\hline
\end{tabular}




\begin{tabular}{|c|c|c|c|c|}
\hline & $\begin{array}{l}\text { is highly effective method for getting } \\
\text { information about sericulture } \\
\text { technologies. }\end{array}$ & & & \\
\hline 30 & $\begin{array}{l}\text { Drip irrigation in mulberry supported } \\
\text { by TSC's helps in improving resource } \\
\text { use efficiency. }\end{array}$ & 0.78 & 78.33 & 3.13 \\
\hline 31 & $\begin{array}{l}\text { TSC's facilitates for improving the } \\
\text { marketing behaviour of farmers by } \\
\text { providing timely marketing } \\
\text { information through SMSs. }\end{array}$ & 0.83 & 83.33 & 3.33 \\
\hline 32 & $\begin{array}{l}\text { Campaigns of TSC's are useful in } \\
\text { educating and disseminating useful } \\
\text { messages to large number of } \\
\text { sericulture farmers in short time. }\end{array}$ & 0.79 & 79.16 & 3.16 \\
\hline 33 & $\begin{array}{l}\text { Study tours organized by TSC's are } \\
\text { useful for getting first hand } \\
\text { information about seed areas and } \\
\text { institution in different regions. }\end{array}$ & 0.78 & 78.33 & 3.13 \\
\hline 34 & $\begin{array}{l}\text { Inclusion of good demonstrations and } \\
\text { farm trials under TSC's helps to } \\
\text { establish local proof on new } \\
\text { technology. }\end{array}$ & 0.77 & 77.50 & 3.10 \\
\hline 35 & $\begin{array}{l}\text { *Inorganic method of cultivation of } \\
\text { mulberry recommended by TSC's } \\
\text { helps in getting higher remunerative } \\
\text { prices of cocoons. }\end{array}$ & 0.79 & 79.16 & 3.16 \\
\hline 36 & $\begin{array}{l}\text { Credibility of TSC's increased due to } \\
\text { Consultancy services in sericulture. }\end{array}$ & 0.78 & 78.33 & 3.13 \\
\hline 37 & $\begin{array}{l}\text { Supply of high yielding }\left(\mathrm{V}_{1}\right) \\
\text { mulberry cuttings/saplings by TSC's } \\
\text { helps to increase area under mulberry. }\end{array}$ & 0.80 & 80.00 & 3.20 \\
\hline 38 & $\begin{array}{l}\text { Living condition of farmers was } \\
\text { improved by intervention of TSC's. }\end{array}$ & 0.85 & 85.00 & 3.40 \\
\hline 39 & $\begin{array}{l}\text { *There is no adequate follow-up of } \\
\text { the training programmes organized by } \\
\text { TSCs. }\end{array}$ & 0.79 & 79.16 & 3.16 \\
\hline 40 & $\begin{array}{l}\text { I feel that TSC provides unique } \\
\text { opportunity for farmers to get need } \\
\text { based technologies. }\end{array}$ & 0.79 & 79.16 & 3.16 \\
\hline
\end{tabular}


Table.2 Final Statements selected for attitude scale after item analysis

\begin{tabular}{|c|c|c|}
\hline S. No. & Statements & t-Values \\
\hline 1 & $\begin{array}{l}\text { The criteria for selecting the farmers to distribution of } \\
\text { subsidized inputs by TSC is appropriate }\end{array}$ & 6.16 \\
\hline 2 & $\begin{array}{l}\text { TSC is play an incredible role in encourage the farmers to take } \\
\text { up sericulture as a main occupation }\end{array}$ & 6.04 \\
\hline 3 & $\begin{array}{l}\text { Digital transfer of subsidy amount by the TSC's to the farmers } \\
\text { account is a novel method to reduce the misuse of funds. }\end{array}$ & 5.69 \\
\hline 4 & $\begin{array}{l}\text { TSC's facilitates for improving the marketing behaviour by } \\
\text { providing timely marketing information. }\end{array}$ & 5.33 \\
\hline 5 & $\begin{array}{l}\text { Mechanization in Sericulture recommended by TSC's reducing } \\
\text { the cost of cultivation. }\end{array}$ & 4.95 \\
\hline 6 & $\begin{array}{l}\text { Drip irrigation in mulberry supported by TSC's helps in } \\
\text { improving resource use efficiency. }\end{array}$ & 4.38 \\
\hline 7 & GPS adopted by TSCs identify real beneficiary of sericulture. & 3.67 \\
\hline 8 & $\begin{array}{l}\text { *Market information disseminated by the TSCs is not useful for } \\
\text { getting remunerative prices for cocoons. }\end{array}$ & 3.58 \\
\hline 9 & $\begin{array}{l}\text { Regular rapport with TSCs facilitates for improvement of } \\
\text { leadership quality in society. }\end{array}$ & 3.55 \\
\hline 10 & $\begin{array}{l}\text { Trench method of mulberry planting supported by TSC's } \\
\text { improves water use efficiency. }\end{array}$ & 3.55 \\
\hline 11 & $\begin{array}{l}\text { The Single window system adopted in TSC's is able to provide } \\
\text { all goods and services at one shop. }\end{array}$ & 3.28 \\
\hline 12 & $\begin{array}{l}\text { Campaigns of TSC's are useful in disseminating information to } \\
\text { large number of sericulture farmers in short time. }\end{array}$ & 3.18 \\
\hline 13 & $\begin{array}{l}\text { Kisan Melas are organized by TSC's at hobli level are useful to } \\
\text { enrich the knowledge on sericulture technologies. }\end{array}$ & 2.79 \\
\hline 14 & $\begin{array}{l}\text { Information transmitted by TSC's through mobile SMS services } \\
\text { is highly effective. }\end{array}$ & 2.77 \\
\hline 15 & $\begin{array}{l}\text { TSCs are working towards improving of farm income of } \\
\text { sericulture. }\end{array}$ & 2.61 \\
\hline 16 & $\begin{array}{l}\text { Extension officials of TSC's are technically sound in running } \\
\text { activities of TSC. }\end{array}$ & 2.52 \\
\hline 17 & $\begin{array}{l}\text { Agri entrepreneurship is possible through TSCs for making } \\
\text { agriculture as an agri business. }\end{array}$ & 2.45 \\
\hline 18 & $\begin{array}{l}\text { * TSCs should work more in non traditional area rather than } \\
\text { traditional sericulture area. }\end{array}$ & 2.02 \\
\hline 19 & TSCs are farmers welfare oriented extension reform. & 1.98 \\
\hline 20 & $\begin{array}{l}\text { *Organic method of cultivation of mulberry recommended by } \\
\text { TSCs is not profitable. }\end{array}$ & 1.97 \\
\hline 21 & $\begin{array}{l}\text { *The programme implemented by TSCs are not need based } \\
\text { leading to loss of credibility among beneficiaries. }\end{array}$ & 1.79 \\
\hline
\end{tabular}


Table. 3 The scoring procedure

\begin{tabular}{|l|c|c|c|c|c|}
\hline $\begin{array}{c}\text { Nature of } \\
\text { the } \\
\text { statement }\end{array}$ & $\begin{array}{c}\text { Strongly } \\
\text { Agree }\end{array}$ & Agree & Undecided & Disagree & $\begin{array}{c}\text { Strongly } \\
\text { disagree }\end{array}$ \\
\hline $\begin{array}{l}\text { Positive } \\
\text { statements }\end{array}$ & 5 & 4 & 3 & 2 & 1 \\
\hline $\begin{array}{l}\text { Negative } \\
\text { statements }\end{array}$ & 1 & 2 & 3 & 4 & 5 \\
\hline
\end{tabular}

\section{Rulons formula}

Rulon gave a formula for estimating the reliability from the scores on two halves of the same test. That reliability is the proportion of true variance in a test. It is the error variance that Rulon estimates from obtained data. If two half-test scores, odds and evens, the differences between these scores can be used to indicate the errors of measurement (Sarmah and Hazarika, 2012).

$r_{t t}=1-\frac{\sigma^{2}{ }_{d}}{\sigma^{2}{ }_{t}}$

Where,

$r_{t t}=$ Rulons Reliability coefficient

$\sigma^{2}{ }_{d}=$ Variance of the raw scores in the test $\sigma^{2}{ }_{t}=$ Variance of the difference of the raw scores on the two halves of the test

The Rulons reliability coefficient $\left(r_{t t}\right)$ value is 0.86 , which explains about 86.00 per cent of scale accuracy. The reliability coefficient of 0.70 or higher is considered "acceptable" in most social science research situations.

\section{Content validity}

It referred to the representativeness or sampling adequacy of the content of a measuring instrument (Kerlinger, 1964). Content validation was carried out by subjecting the selected attitude items to judge's opinion. Experts in the selected field of study were the judges. They were asked to indicate the extent to which each attitude item covered the different aspects of attitude of sericulture farmers towards TSCs or judge each item for its presumed relevance to the property being measured. The judges were asked to indicate their relevancy with each statement on four point continuums ranging from "More Relevant" to "Not Relevant". The scoring pattern adopted was 'More Relevant' (4) response, 'Relevant (3) response', 'Least Relevant (2) and 'Not Relevant' (1) response.. Totally 30 judges responded by sending their judgements. The content validity of the scale of the mean score was fixed by calculating the total score continuum divided by number of point continuum categories. The value obtained was 2.5 so if the overall mean score of the attitude items as rated by the judges was above 2.5 , the scale will be declared as valid and if not otherwise. In the present case, the overall mean relevancy score was worked out as 3.21. Therefore, the constructed attitude scale is said to be valid.

\section{Administration of the scale}

The 21 selected were arranged randomly in order to avoid biased responses. A five-point continuum of 'strongly agree', 'agree', 'undecided' 'disagree' and 'strongly disagree' was used as response categories. The scoring procedure adopted is as follows. 
This scale was administered to obtain TSCs beneficiary responses. The score obtained for each statement was summed up to arrive at the attitude score for that respondent. The score ranged from 105 (maximum) to 21 (minimum). The responses were grouped as less favourable, moderately favourable and highly favourable based on the mean and standard deviation.

In conclusion, an attitude of Sericulture farmers towards TSC activities is measured by constructing scales to measure reliability and validity of attitude statements; it helps to get valid response from the respondents. The scale constriction is inevitable for measuring attitude.

\section{References}

Edwards, A.L. 1957. Techniques of attitude scale construction. Vakils, Feffer and Simons Private Ltd. 9 Sport Road, Ballard Estate, Bombay (Mumbai).

Kerlinger, F. N. 1964. Foundations of behavioural research, Holt Rinehart and Winston Inc., New York, p. 379.

Likert, R.A. 1932. A Technique for the Measurement of Attitude Scales, Psychol, New York, No 140.

Sarmah H. K and Hazarika B. 2012. Determination of Reliability and Validity measures of a questionnaire . Indian Journal of Education and Information Management. 1(11):507517.

\section{How to cite this article:}

Harisha, N., B. Mukunda Rao, T. Gopi Krishna, M. Uma Devy and Nafeez Umar, S. K. 2020. Scale Construction for Measuring the Attitude of Sericulture Beneficiary Farmers towards the Activities of Technical Service Centres (TSCs). Int.J.Curr.Microbiol.App.Sci. 9(08): 27782787. doi: https://doi.org/10.20546/ijcmas.2020.908.313 